Article

\title{
Investigation of Morphological Changes in the Tamsui River Estuary Using an Integrated Coastal and Estuarine Processes Model
}

\author{
Tung-Chou Hsieh ${ }^{1, *} \mathbb{D}$, Yan Ding ${ }^{2,3}{ }^{\oplus}$, Keh-Chia Yeh ${ }^{1}$ and Ren-Kai Jhong ${ }^{4}$ \\ 1 Department of Civil Engineering, National Chiao Tung University, Hsinchu 30010, Taiwan; \\ kcyeh@mail.nctu.edu.tw \\ 2 National Center for Computational Hydroscience and Engineering, University of Mississippi, \\ University, MS 38677, USA; Yan.Ding@erdc.dren.mil \\ 3 U.S. Army Engineer Research and Development Center, Coastal and Hydraulics Laboratory, \\ Vicksburg, MS 39180, USA \\ 4 Disaster Prevention and Water Environment Research Center, National Chiao Tung University, \\ Hsinchu 30010, Taiwan; tkuxdwang@gmail.com \\ * Correspondence: travis0310@gmail.com; Tel.: +886-919-378-324
}

Received: 16 March 2020; Accepted: 8 April 2020; Published: 10 April 2020

check for updates

\begin{abstract}
This study is to investigate morphological changes in the Tamsui River Estuary in Taiwan driven by multiple physical processes, such as river flows, tides, waves, and storm surges, and then to study the impacts of sediment flushing operated at the Shihmen reservoir upstream on the river estuary. An integrated coastal and estuarine processes model (CCHE2D-Coast) (Center for Computational Hydroscience and Engineering Two-Dimensional-Coast) was validated by simulating these physical processes in the estuary driven by three historical typhoons in 2008. The site-specifically validated model was then applied to simulate morphological changes in the estuary in response to reservoir sediment flush scenarios from the upstream. For the impact assessment of sediment flushing, a synthetic hydrological event was designed by including a historical typhoon and a typical monsoon. It was found that during the typhoon, the sediments will be mostly deposited in the estuarine river reach of Tamsui and the Wazihwei sandy beach. During the monsoon period, most of the sediments tend to be deposited in the second fishing port of Tamsui, the northern breakwater, and the estuary, while the Wazihwei sandy beach in the river mouth would be scoured by backflow. Simulations of the complex flow fields and morphological changes will facilitate the best practice of sediment management in the coastal and estuarine regions.
\end{abstract}

Keywords: coastal process model; wave; sediment transport; morphological change; coastal and estuary management

\section{Introduction}

Heavy rainfall, waves, storm surges, and high tides during cyclone (typhoon or hurricane) periods cause hazards, such as flooding/inundation and shoreline erosion in coastal areas. A full understanding of the behavior of water bodies and their movement in estuarine areas during cyclone periods is essential for flood control, disaster mitigation, coastal erosion protection, and coastal structure preservation. Integrated coastal and estuarine process models (ICEPM) can simulate multiple physical processes, such as tides, waves, surges, river flows, wind, sediment transport, and morphological changes, e.g., [1-5]. They are applicable to study hydrodynamic and morphodynamic processes in response to what-if scenarios of coastal protection practices, and, therefore, facilitate safety assessment 
of estuarine areas and the determination of coastal management measures to prevent or reduce disasters and to stabilize shorelines.

Surrounded by seas on all sides, Taiwan is subjected to 3-4 typhoons on average per year. The Tamsui River is the largest river in northern Taiwan, and variations of erosion and deposition on the river bed are closely related to flows and sediment transport in the adjacent marine waters (Figure 1). In recent years, owing to the construction of the Taipei Port, the littoral drift in the estuary and adjacent coastal areas has been gradually changed, which affects the adjacent coastal terrain and landscape [6]. In addition, serious siltation occurs in the Shihmen Reservoir upstream of the Tamsui River, with the total siltation in the Shihmen Reservoir reaching 1.86 million $\mathrm{m}^{3}$ by the beginning of 2017-a volume accounting for $32.6 \%$ of the designed water-storage capacity of the reservoir [7]. To alleviate the reservoir siltation problem, meet the industrial water demand, and extend the reservoir life, the Water Resources Agency of the Ministry of Economic Affairs plans to add a desilting tunnel under the water storage limit of the Shihmen Reservoir at the Amuping and Dawanping areas [8]. The Amuping desilting tunnel is expected to be completed by 2022, and it will lead to changes in the amount of sediment transport in the Tamsui River and indirectly affect the sediment transport equilibrium between the river and the sea.

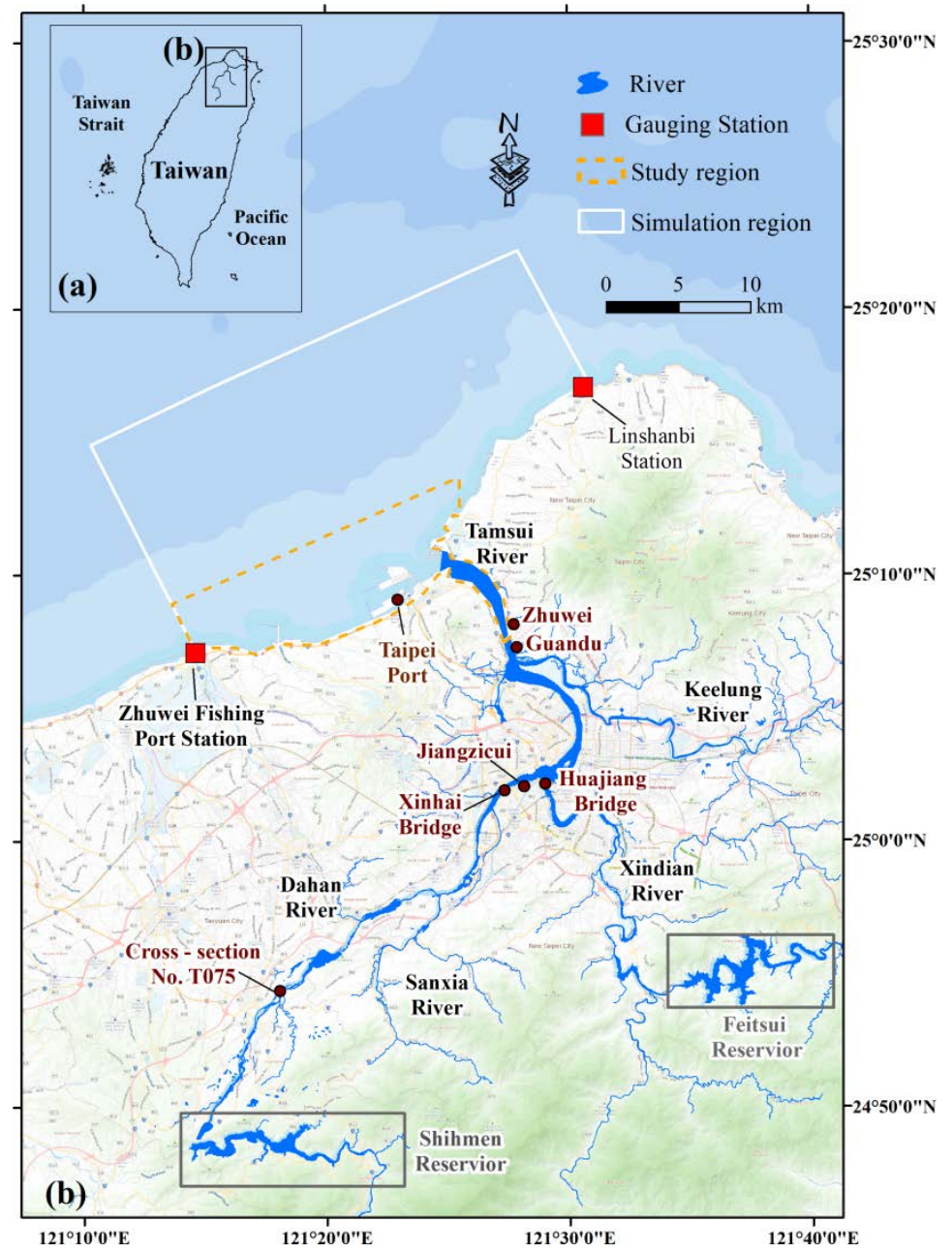

Figure 1. Tamsui River catchment of Taiwan.

For assessing the impact of sediment management plans, such as reservoir sediment flushing, on the sediment transport and morphological changes in the Tamsui River Estuary and its adjacent coasts, it is necessary to apply numerical models to predict the spatiotemporal redistribution of sediments from the reservoir into the areas downstream. For this impact assessment of sediment flushing, it is 
important to apply a validated numerical model, which can demonstrate its capability to reproduce flows, waves, sediment transport, and morphological changes in the estuary. This requires integrated coastal and estuarine processes modeling by taking into account all the hydrological forces, such as river flows, tides, waves, storm surges, and wind-induced currents, along with the movement of sediment in the river and that flushed from the reservoir.

In the shallow coastal zone, the flow near the bottom, which drives sediment transport and causes bed changes, is composed mainly of wave motion and mean currents. The mean current in coasts and estuaries may be a combination of tidal flows, river flows, wave-phase-averaged currents, etc. Interaction of wave and current is a highly nonlinear process, particularly in coastal and estuarine areas. Since the 1970s, many studies have been conducted by experimental methods to explain the wave-current boundary layer interaction ([9-23]) on the theoretical side. Wave-current interaction can be simulated by using the so-called wave-phase-resolving numerical models [24,25], which are usually computationally costly. For long-term and large-scale simulations, the phase-averaged models [26,27] are often used to provide engineering answers to coastal problems, such as dredging, erosion, flooding/inundation, etc.

It is important to simulate sediment transport and morphological changes by taking into account the combination of wave and current. The high shear velocity within the bottom boundary layer produces strong turbulence and large bed shear stresses impacting on the current, bringing increased bottom resistance in the presence of combined flow [28]. Hence, the combined wave-current flow is the basic element on sediment transport, mixing processes, diffusion, and other important coastal phenomena. Therefore, some researchers determine physical mechanisms by analyzing the combined flow over smooth or rough beds, both experimentally and numerically [29,30].

By developing the numerical models and experiments, researchers have analyzed that the sandpit morphodynamics might be caused by wave transformation, refraction, and diffraction induced by the pit itself. Van Rijn [31] developed a mathematical model to predict the sedimentation of dredged channels by waves and currents. Roos et al. [32] developed an idealized process-based morphodynamic model for the evolution of large-scale sandpits in a tide-dominated offshore environment. Benedet and List [33] use a numerical model to evaluate the effects of bathymetric features, such as dredged borrow areas, on the formation of erosion hot spots. Faraci et al. [34] conducted experimental to explain the possibility of exploiting sandpits at intermediate and shallow water depths.

Most of the existing storm-surge models can be used to simulate the storm surge-induced coastal flooding, such as the POM (Princeton Ocean Model) [35], SLOSH (Sea, Lake and Overland Surges from Hurricanes) [36,37], and SHORECIRC (Quasi-3D NearSHORE CIRCulation Model) [38,39] models, but they are unable to consider sediment transport processes and bed variations when simulating coastal hydrodynamics. Since 1996, scholars have developed the ICEPM to simulate dynamic changes in coastal morphology, including shoreline changes, erosion, barrier breaching, and dam break [1,40-43]. This model is an integrated product of the wave spectrum, tidal current with wave effects (considering the radiation stress effect), sediment transport, and bed variation models with the computing process. By introducing an empirical sediment transport formula, the ICEPM allows calculating long-term morphological changes [2,3], whereas the computational period and relevant parameters need to be verified using actual data of morphological changes. Some researchers also estimate long-term changes in estuaries and lagoons using empirical semi-numerical approaches, such as tidal averaging and rapid morphologic assessment [4]. However, such types of tidal-averaging models mostly adopt the tidal phase averaging for computing, and thus, are unable to effectively simulate the maximum waves and surges caused by a typhoon and the resulting flooding event. Moreover, the abundant rainfall brought by a typhoon will lead to an increase in the upstream flood volume, which in turn will transport more sediment to the estuary, thereby making the estuarine flow field more complicated. To find maximum sedimentation and erosion is one of the important tasks in the impact assessment of hazardous typhoons and sediment flushing operations upstream the estuary. For the purpose, it is 
necessary to simulate all the hydrodynamic and morphodynamic processes in the estuary, including wave dynamics, river hydrology, oceanography, and sediment transport mechanics.

CCHE2D-Coast $[5,44]$ is an integrated ICEPM model, capable of simulating these multiple coastal and estuarine processes. By using empirical sediment transport formulas, this model can simulate sediment transport driven by waves and currents in coasts and estuaries, and, therefore, enable the simulation of morphological changes in a wide region from the river upstream to the river mouth, and coasts. Through many years of development, validation, and improvement, this model demonstrated its applicability to help engineering planning and design of coastal flood and erosion protection by considering complex hydrological and morphological conditions in estuaries [3,5,45]. The wave model of CCHE2D-Coast has the following major features: (1) It simulates deformation and transformation of irregular waves in coastal and estuarine conditions, including wave breaking, refraction, diffraction, and interaction of wave and current at river mouth [27]; (2) it considers the effect of wave roller due to breaking to compute more accurate radiation stresses to include the effect of varying vertical mean current structure in the surf zone. The sediment transport model takes into account the effect of combined waves and currents in an estuary [5]. This model has been successfully applied to study the sediment transport and flood flows in the Touchien River Estuary, Hsinchu, Taiwan, and it has provided numerical results of flow and morphological changes under the conditions of various planning scenarios [5,45]. Therefore, this model was selected to simulate sediment transport and morphological changes in a river estuary such as Tamsui River Estuary, which are mainly driven by coastal waves, tidal currents, and river inflows.

Since the construction of the Taipei Port in 1993, the Tamsui River estuary has undergone changes in the type of sediment movement. According to the statistics of Shihmen Reservoir's discharge and sediment delivery ratio during 2006-2017, the sediment delivery ratio has been tending to increase since the desilting tunnel of Shihmen Reservoir was put into use for the first time in 2013 [8]. The Amuping desilting tunnel of Shihmen Reservoir is expected to be completed in 2022, and it will further change the conditions of the water-sediment at the Tamsui River estuary. Therefore, this study used CCHE2D-Coast to explore the changes in the scouring and aggradation of the Tamsui River estuary after the opening of the Amuping desilting tunnel.

The rest of the paper is organized as follows: Section 2 provides a brief introduction of the integrated coastal and estuarine processes model, CCHE2D-Coast. Section 3 gives more information on the model for the study area, the Tamsui River estuary. Section 4 is for model validation and model skill assessment results by simulating hydrodynamic and morphological changes through the 2008 typhoon season. Section 5 provides simulation results and discussions for sediment flushing from the Shihmen reservoir. Finally, Section 6 concludes the paper and gives some preliminary suggestions on the management of flood and sediment in the estuary.

\section{Brief Description of the Integrated Coastal and Estuarine Model}

An integrated river/coastal/estuarine process modeling system, CCHE2D-Coast [5,44], was used to simulate the coupled hydrodynamic and morphodynamic processes driven by waves, tides, storm surges, and sediment transport for assessment of flooding and sedimentation in the Tamsui River Estuary (Figure 2). CCHE2D-Coast contains a number of submodels for simulating the deformations and transformations of irregular/multidirectional waves, tropical cyclonic barometric pressure, and wind fields along storm tracks, tidal, and wave-induced currents, and morphological changes. For computing irregular waves, a multi-directional spectral wave action equation was adopted in the wave spectral module. It is capable of modeling wave deformation/transformation processes from deepwater to shallow water for nonbreaking and breaking waves, including wind-generated waves and whitecapping effects. For coastal structures, the wave model can take into account the transmission effect of wave energy through a permeable structure (e.g., a rubble mount breakwater). The flow model was used to simulate multi-scale hydrodynamic processes of free-surface water flows, such as river 
flows, tidal currents, nearshore currents, and storm surges. A non-orthogonal structured grid was used for all simulation models of waves, currents, sediment transport, and morphological changes.

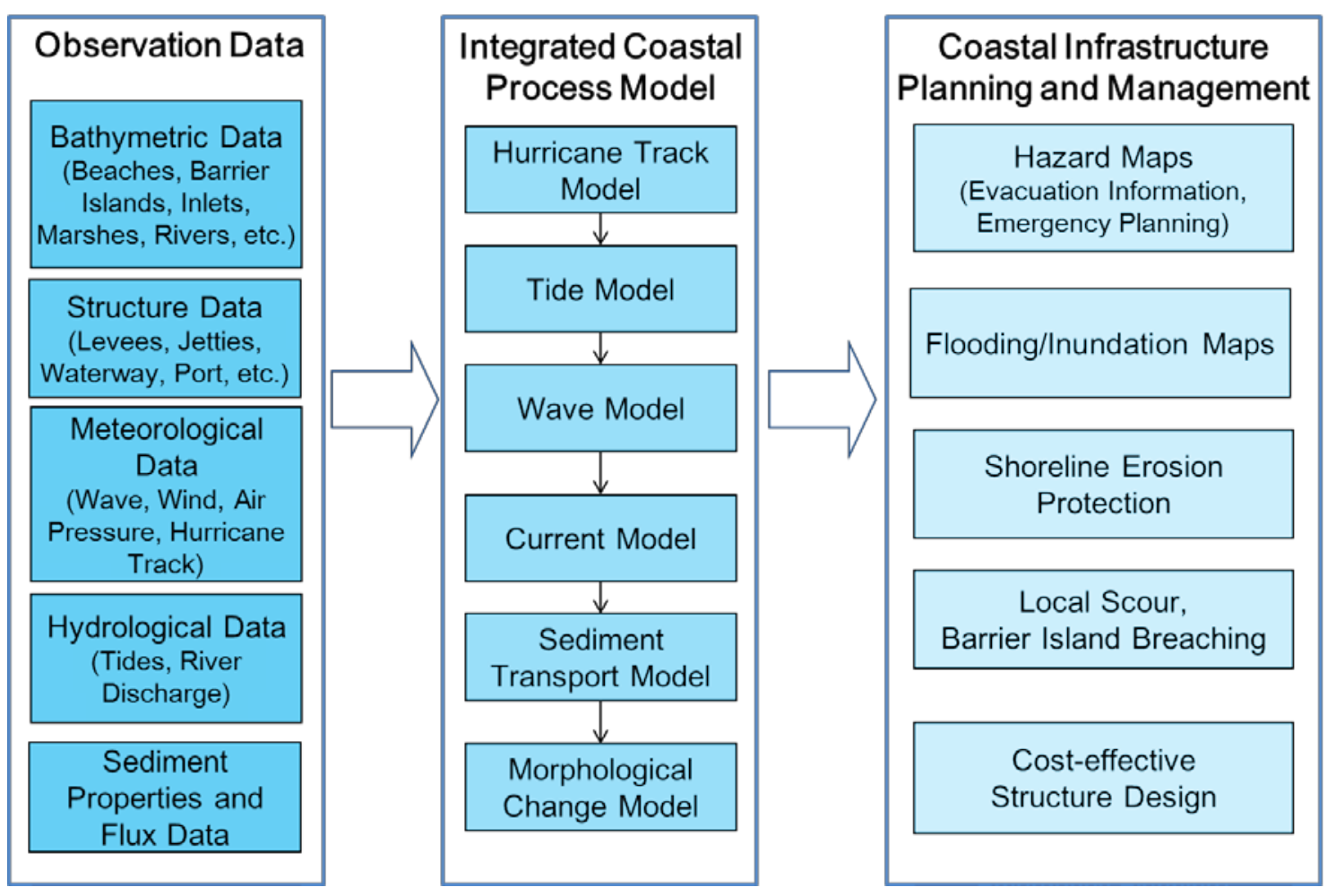

Figure 2. CCHE2D-Coast is a fully integrated numerical model system for simulating waves, currents, and morphological changes.

In the current module, the two-dimensional (2-D) depth- and shortwave-averaged shallow water equations with wave forcing were employed to simulate the flows driven by wave radiation stresses, tides, storm surges, river inflows, the Coriolis force, and turbulence in surf zones. This hydrodynamic model provides users with two options to calculate the wave radiation stresses: one is the traditional wave stress formulations by means of the sinusoidal wave assumption of the linear small-amplitude wave theory; another is the improved radiation stresses formulae derived from the non-sinusoidal wave assumption, which enables the three-dimensional (3-D) features of vertical current structures (e.g., surface rollers or undertow currents) in the surf zone to be taken into account [44].

In the sediment transport submodel, empirical sediment transport models were used to calculate the sediment transport rates of bed materials and the suspended sediment under the conditions of combined waves and currents. A unified sediment transport model [3] was used to calculate the sediment flux from upstream rivers to estuaries and coasts to consider the sediment transport seamlessly from the non-wave environment at a river to the wave-current interaction area at an estuary and a wave-dominant coastal zone. The local sediment transport rate vector $\vec{q}$ can be written as follows:

$$
\vec{q}=\vec{q}_{c}+\vec{q}_{w}=\frac{\tau_{m}-\tau_{c}}{\rho g}\left(A_{c} \vec{u}+A_{w} F_{D} \vec{u}_{b}\right)
$$

where $\vec{q}_{c}$ and $\vec{q}_{w}$ are the local sediment transport rates due to current and wave, respectively. $\tau_{m}$ is the maximum bottom shear stress which has been modified to consider the difference of the stress in river flows and nearshore currents, $\tau_{c}$ is the critical shear stress for moving bed materials, $\rho$ is the water density, $\mathrm{g}$ is the gravitational acceleration, $\vec{u}$ is the velocity vector of mean current, $\vec{u}_{b}$ is the wave orbital velocity at the bottom, $A_{c}$ and $A_{w}$ are the empirical coefficient for sediment transport driven by 
mean currents and waves, respectively, $F_{D}$ is a direction function $(=-1$ for offshore, +1 for onshore). By using computed mean velocity and wave orbital velocity, the maximum bottom stress is calculated as follows:

$$
\tau_{m}=\rho C_{f}\left|\vec{u}+\vec{u}_{b}\right|^{2}
$$

where $C_{f}$ is the bottom friction coefficient due to current and wave [44]. For detailed information on the sediment transport model, one may further refer to Ding and Wang (2007) [3] and Ding et al. (2016) [44].

Morphological changes were computed based on the mass balance of sediments, in which the diffusive transport for the anisotropic downslope gravitational effect was also included [41]. The wetting and drying process was properly modeled to handle water level variations and bed changes.

This integrated processes model (CCHE2D-Coast) provides a variety of boundary conditions for computing wave actions, currents, sediment transport, and morphological changes. On the offshore boundary, wave spectral energy density was given by using the parametric wave spectrum defined by observed wave parameters in offshore buoys. Tidal levels were also specified on the offshore by using observed water level data or astronomical tidal level predictions. For river inflows upstream, hydrographs (time histories of discharge) can be given by observation data at hydrological stations or other model estimations. On the boundaries upstream for inputting river inflows, one may also give sediment transport fluxes based on measured (or planned) sediment release/flushing rates from hydraulic structures upstream, such as dams and reservoirs. The sediment transport fluxes can also be calculated by using a sediment transport formulation, such as Equation (1), by assuming the state of sediment transport through the boundaries is close to equilibrium. In general, it is assumed that no bed changes along the offshore boundaries occur through the computational period. More specific information on the boundary conditions for the present study in the Tamsui River Estuary is provided in the following sections.

The simulations performed with this integrated model are also supported by a user-friendly interface (CCHE2D-GUI) [46], which assists users to generate computational grids, specify boundary conditions and model parameters, and monitor and visualize the simulation results. All the submodels work with the same computational grid. Thus, the wave and flow models run on the same computational cores, passing information between submodels through the local memory/cache. It does not need to switch any additional executable codes during computations. All simulations are performed efficiently on a PC.

CCHE2D-Coast has been validated by simulating waves and storm surges induced by hurricanes in the Gulf of Mexico and investigating the impact of sea-level rise on morphological changes in the Touchien River estuary, Hsinchu, Taiwan [5]. The validated CCHE2D-Coast model was applied to the feasibility studies of coastal protection plans, such as those for river channel dredging and layout of new coastal structures in the Touchien River Estuary [45].

\section{Study Area and Construction of the Numerical Model}

\subsection{Study Area}

The Tamsui River is the largest river in northern Taiwan, which is composed of major tributaries, such as the Dahan River, Xindian River, Keelung River, and Sanxia River, with a total drainage area of 2726 square km (Figure 1). The main stream of the Tamsui River is 24 km long, with the Dahan River and Xindian River confluencing at Jiangzicui (on whose two banks the Xinzhuang and Manka districts are located), and the Keelung River confluencing downstream at Guandu. It forms sandbars under the Huajiang Bridge as well as at Guandu and Zhuwei along the flow path, which are the most important northern reserve for waterfowl and mangrove.

The amount of sediment transport of the whole Tamsui River basin is approximately 9.28 million $\mathrm{m}^{3}$ per year. However, due to presence of the Shihmen Reservoir, Feitsui Reservoir, and sediment barriers, the actual amount of sediment transport in the middle reaches is approximately 1.85 million 
$\mathrm{m}^{3}$ per year, of which about $85 \%$ corresponds to the suspended load transport- 1.25 million $\mathrm{m}^{3}$ per year, whereas the bedload transport rate is 0.185 million $\mathrm{m}^{3}$ per year. The peak discharge at Tamsui River estuary can reach more than $2000 \mathrm{~m}^{3} / \mathrm{s}$ under typhoon rainstorms, making the Tamsui River one of the main sediment sources of the coastal waters [6]. The river section from the estuary to the Xinhai Bridge of the Dahan River is a tideway, where the water level of the river changes with the rise and fall of the tidal level in the sea, accompanied by a reciprocal movement of the river water flow with the tidal movement. There is a close relationship between the scouring and aggradation balance and the sediment transport behavior of the adjacent coastal waters. Either the invasion of a typhoon or the sediment discharge of the upstream reservoir, they all lead to morphological changes in the Tamsui River estuary.

To explore the effect of the Shihmen Reservoir sediment discharge on the Tamsui River estuary, this study selected the Guandu Bridge on the Tamsui River as the upstream boundary, with the selected sea area ranging from the north-bank TN08 section of the Tenth River Management Office to its south-bank TS35 section, where the total shore length was $21 \mathrm{~km}$. The study area extended seawards from 3 to $5 \mathrm{~km}$ (water bottom elevation of $-20 \mathrm{~m}$ ). The simulation range included the Tamsui, Bali, and Linkou districts, with the coast comprising a mixed terrain of sand and rock. There are many concave bays along the coast, and beaches are developed in the coves, such as the strip-shaped sandy beaches of Qianshui Bay, Zhouzi Bay, and Shalun. Owing to the complicated longshore currents, the sand shore is susceptible to erosion. In the Tamsui River estuary, the southern shore between Bali and Linkou is affected by the development of Taipei Port and the estuarine sediment transport, and as a result, the Bali section of the shore in the northern section of the port is currently subjected to siltation. In contrast, the south side of the port (Linkou section) shows an erosion trend. The overall coastal situation within the study area is presented in Figure 3.

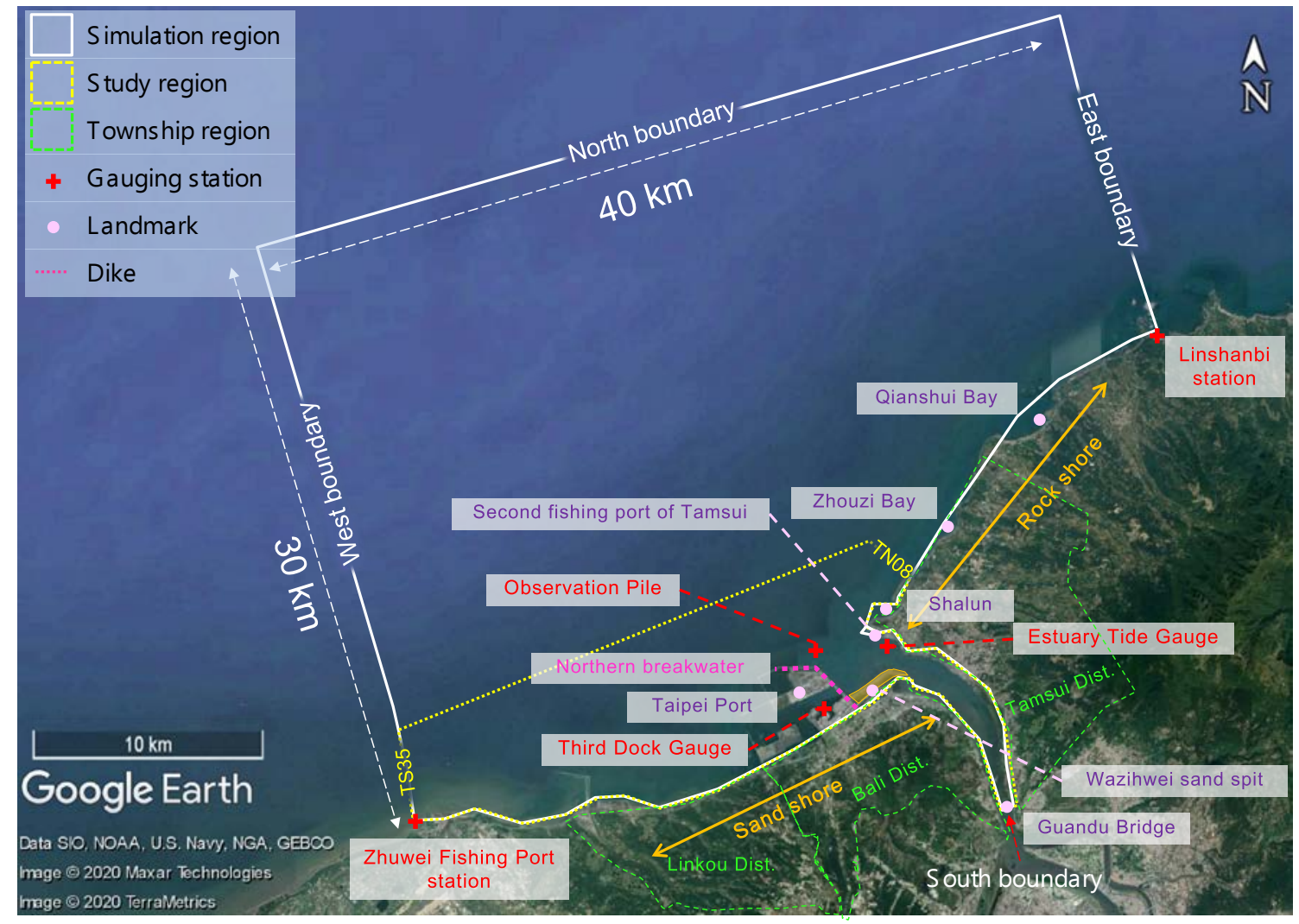

Figure 3. Study region, simulation region, and relevant monitoring sites. 


\subsection{Model Configuration}

The numerical elevation data used in this study were measured by the Institute of Harbor and Marine Technology, Ministry of Transportation and Communications [47]. The complete topo-bathymetric data was available for the years of 2006-2013, covering the river channel from the Guandu Bridge to the estuary and also covering the area that extended seawards approximately 3-5 km (water bottom elevation of $-20 \mathrm{~m}$ ); the selected sea area ranged from the north-bank TN08 section of the Tenth River Management Office to its south-bank TS35 section. If the monitoring data of this region were used to explore estuarine changes, the sea area would be too small to reflect the characteristics of waves and currents properly. Thus, the north shore of this sea area was extended to Linshanbi (with the corresponding topo-bathymetric data of the year 2008). The river flow path was adjusted using satellite image data, and the 2008 events of Typhoon Fung-Wong, Typhoon Sinlaku, and Typhoon Jangmi were included in this study as validation cases to verify the relevant parameters of the model.

The simulation model boundaries shown in Figure 3 cover the study area expanding $40 \mathrm{~km}$ and $30 \mathrm{~km}$ in the east-west and north-south directions, respectively. Non-orthogonal quadrilateral meshes were generated by using CCHE-GUI [46] with the total number of 156,349 nodes $(289 \times 541)$ in the computational domain. The grid resolutions varied from $20 \mathrm{~m}$ at the river mouth to $500 \mathrm{~m}$ in the offshore. The eastern boundary crossed the Linshanbi station, while the western boundary lay approximately at the Zhuwei Fishing Port station. The southern boundary of the river was placed at the Guandu Bridge.

The monitoring data at the east and west boundaries were measured by two tide-gauge stations of the Central Weather Bureau, the Linshanbi station and the Zhuwei Fishing Port station, respectively (Figure 3). The monitoring data at the north boundary included wind speed, wind direction, and waves, all adapted from the monitoring data of the outside sea area of the Taipei Port. For the southern boundary, the data were obtained by simulating the hydrograph of flow and sediment concentration at the Guandu Bridge based on CCHE1D, a verified numerical model suited for modeling the scouring and aggradation in one-dimensional river channels. The upstream boundary data in CCHE1D were derived from the measured hydrograph of flow and sediment concentration at the Shihmen Reservoir; the downstream boundary data were the measured tidal level in the Tamsui River estuary [6]. The bed particle size was adapted from the survey led by the Tenth River Management Office titled "Evaluation of the Impacts of Tamsui River Sediment Transport on Adjacent Coasts" and taken as the median particle size $d_{50}=0.2 \mathrm{~mm}$. For sediment transport, its total load was calculated. The Manning roughness coefficient was set to 0.02 in the outside sea area and 0.025 in the river area.

\section{Numerical Model Validation and Statistic Error Analysis}

This study used the 2008 events of Typhoon Fung-Wong, Typhoon Sinlaku, and Typhoon Jangmi to carry out the model validation. The starting and ending times of each typhoon event are listed in Table 1 . The topo-bathymetric data used in the model were measured using single-beam echosounders in May 2008. The tidal levels at the west and east boundaries were given by measured tidal gauge data at the Linshanbi and Zhuwei Fishing Port stations. The wind data measured at the Taipei Harbor meteorological station were used to generate time-dependent and spatially-uniform wind fields. The peak flows in the three typhoon-induced flood events were 3798,6476 , and $7332 \mathrm{~m}^{3} / \mathrm{s}$, respectively, whereas the sediment concentration was controlled by the sediment discharge operation of the stream Shihmen Reservoir, with the maximum concentration of $45,042 \mathrm{~kg} / \mathrm{s}$ occurring during the period of Typhoon Sinlaku (Figure 4). It was assumed that the flow at the Guandu Bridge was $50 \mathrm{~m}^{3} / \mathrm{s}$, and the sediment concentration was $0 \mathrm{~kg} / \mathrm{s}$ in the absence of flood drainage at the reservoir. The simulation period ranged from 17:00 on 23 July 2008 to 00:00 on 1 October 2008, totaling 1675 hours. The model was spun up by computing the tide flows from 17:00 on 23 July 2008 before introducing Typhoon Fung-Wong, in which the time step was set to $30 \mathrm{~s}$. After the spin-up, the wave-current interaction for modeling morphological changes was conducted for 66 days until the end of Typhoon Jangmi at 00:00 
on 1 October 2008. Then, the time step for computing flows was changed to $10 \mathrm{~s}$; the time step for updating bed elevations was $100 \mathrm{~s}$. The wave field was recomputed every one hour based on the latest flow field.

Table 1. Starting and ending times and duration of the typhoon events used in model validation.

\begin{tabular}{cccc}
\hline Typhoon Name & Starting Time & Ending Time & Duration (day) \\
\hline Typhoon Fung-Wong & 26 July 2008 7:00 & 30 July 2008 0:00 & 4 \\
Typhoon Sinlaku & 10 September 2008 23:00 & 18 September 2008 0:00 & 7 \\
Typhoon Jangmi & 26 September 2008 23:00 & 1 October 2008 0:00 & 4 \\
\hline
\end{tabular}

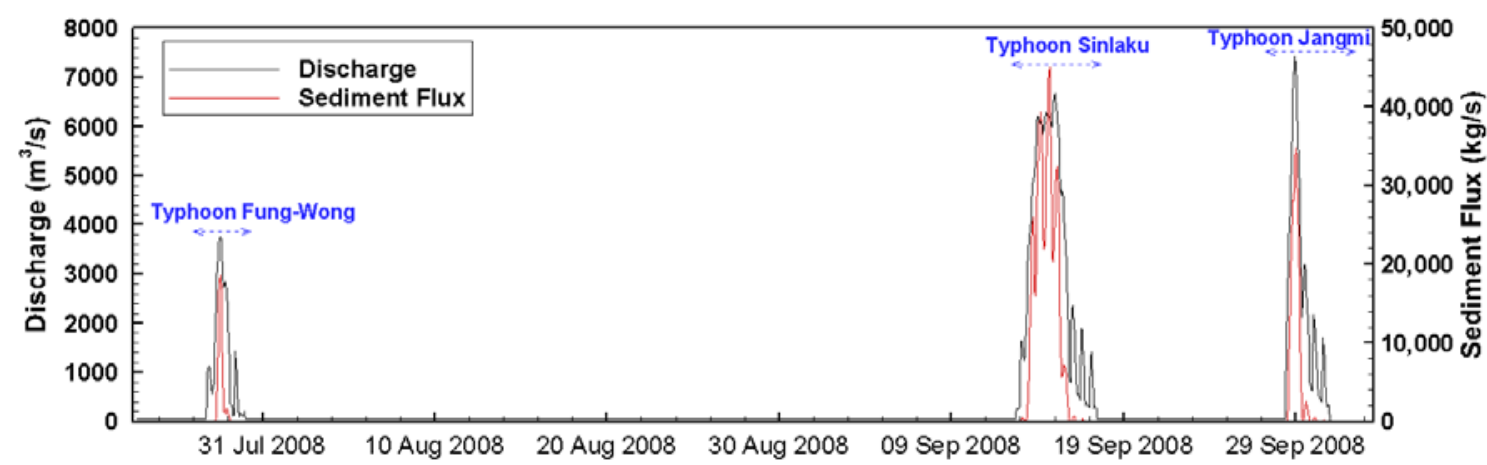

Figure 4. Time series of river flow and sediment concentration at the Guandu Bridge (validation cases).

To quantify the difference between the calculated results and the observed values, this study employed the four parameters, such as the root-mean-square error (RMSE), the Pearson correlation coefficient $(r)$, the scatter index $(S I)$, and the normalized bias $(N B)$. The calculation results of these parameters at three stations (the locations are marked in Figure 3) are listed in Table 2. The RMSE was used to quantify the deviation between the simulated and observed values; $r$ was used to evaluate the correlation between the simulated and observed values; SI was the ratio of the standard deviation between the simulated and observed values to the mean of the observed values; the indicator $N B$ evaluated the extent to which the calculated results were overestimated or underestimated relative to the true values. RMSE, $r, S I$, and NB can be calculated using the following expressions:

$$
\begin{gathered}
R M S E=\sqrt{\frac{\sum_{i=1}^{N} E_{i}^{2}}{N}} \\
r=\frac{\sum_{i=1}^{N}\left(m_{i}-\bar{m}\right)\left(O_{i}-\bar{O}\right)}{\sqrt{\sum_{i=1}^{N}\left(m_{i}-\bar{m}\right)^{2} \sum_{i=1}^{N}\left(O_{i}-\bar{O}\right)^{2}}} \\
S I=\frac{\sqrt{\frac{1}{N} \sum_{i=1}^{N}\left(E_{i}-\bar{E}\right)^{2}}}{\frac{1}{N} \sum_{i=1}^{N}\left|O_{i}\right|} \\
N B=\frac{\frac{1}{N} \sum_{i=1}^{N} E_{i}}{\frac{1}{N} \sum_{i=1}^{N}\left|O_{i}\right|}
\end{gathered}
$$

where $E_{i}$ is the error between the simulated value $m_{i}$ and observed value $O_{i}$ in the simulation time series, i.e., $m_{i}-O_{i} ; N$ is the total number of the observations; $\bar{E}$ is the average error of the simulated value expressed as $(1 / N) \sum_{i=1}^{N}\left|E_{i}\right| ; \bar{O}$ is the average observed value expressed as $(1 / N) \sum_{i=1}^{N} O_{i} ; \bar{m}$ is the average simulated value expressed as $(1 / N) \sum_{i=1}^{N} m_{i}$. 
Table 2. Calculated results of the root-mean-square error (RMSE), the Pearson correlation coefficient $(r)$, the scatter index $(S I)$, and the normalized bias (NB) for tidal level, wave height, and wave period in the typhoon events at three stations: Tamsui River Estuary tide gauge (a.k.a. Estuary Tide Gauge), Observation pile outside the Taipei Port (a.k.a. Observation Pile), and Third dock Inside the Taipei Port (a.k.a. Third Dock Gauge), of which locations are shown in Figure 3.

\begin{tabular}{|c|c|c|c|c|c|c|c|c|}
\hline $\begin{array}{l}\text { Starting } \\
\text { Time }\end{array}$ & $\begin{array}{l}\text { Ending } \\
\text { Time }\end{array}$ & $\begin{array}{l}\text { Typhoon } \\
\text { Name }\end{array}$ & $\begin{array}{l}\text { Monitoring } \\
\text { Site }\end{array}$ & $\begin{array}{l}\text { Monitoring } \\
\text { Data Type }\end{array}$ & $\begin{array}{l}\text { RMSE } \\
\text { (m) }\end{array}$ & $r$ & $S I$ & $N B$ \\
\hline \multirow{5}{*}{27 July 2008} & \multirow{5}{*}{$\begin{array}{l}30 \text { July } \\
2008\end{array}$} & \multirow{5}{*}{$\begin{array}{l}\text { Typhoon } \\
\text { Fung-Wong }\end{array}$} & $\begin{array}{l}\text { Estuary Tide } \\
\text { Gauge }\end{array}$ & Tidal level & 0.10 & 0.99 & 0.16 & 0.04 \\
\hline & & & $\begin{array}{l}\text { Observation } \\
\text { Pile }\end{array}$ & Tidal level & 0.34 & 0.99 & 0.19 & 0.46 \\
\hline & & & $\begin{array}{c}\text { Third Dock } \\
\text { Gauge }\end{array}$ & Tidal level & 0.32 & 1.0 & 0.71 & -0.35 \\
\hline & & & $\begin{array}{l}\text { Observation } \\
\text { Pile }\end{array}$ & $\begin{array}{c}\text { Significant } \\
\text { wave height }\end{array}$ & 0.59 & 0.65 & 0.61 & -0.17 \\
\hline & & & $\begin{array}{l}\text { Observation } \\
\text { Pile }\end{array}$ & $\begin{array}{c}\text { Significant } \\
\text { wave period }\end{array}$ & 1.58 & 0.67 & 0.31 & -0.13 \\
\hline \multirow{5}{*}{$\begin{array}{c}12 \text { September } \\
2008\end{array}$} & \multirow{5}{*}{$\begin{array}{c}2 \\
\text { October } \\
2008\end{array}$} & \multirow{5}{*}{$\begin{array}{l}\text { Typhoon } \\
\text { Sinlaku, } \\
\text { Typhoon } \\
\text { Jangmi }\end{array}$} & $\begin{array}{c}\text { Estuary Tide } \\
\text { Gauge }\end{array}$ & Tidal level & 0.16 & 0.99 & 0.16 & 0.13 \\
\hline & & & $\begin{array}{l}\text { Observation } \\
\text { Pile }\end{array}$ & Tidal level & 0.26 & 0.99 & 0.19 & 0.28 \\
\hline & & & $\begin{array}{c}\text { Third Dock } \\
\text { Gauge }\end{array}$ & Tidal level & 0.35 & 0.99 & 0.71 & -0.34 \\
\hline & & & $\begin{array}{l}\text { Observation } \\
\text { Pile }\end{array}$ & $\begin{array}{c}\text { Significant } \\
\text { wave height }\end{array}$ & 0.42 & 0.93 & 0.33 & 0.13 \\
\hline & & & $\begin{array}{l}\text { Observation } \\
\text { Pile }\end{array}$ & $\begin{array}{l}\text { Significant } \\
\text { wave period }\end{array}$ & 0.58 & 0.92 & 0.12 & -0.01 \\
\hline
\end{tabular}

In the simulation range, tidal level gauges were installed in the Tamsui River estuary, the third dock in the Taipei Port, and the observation pile outside the Taipei Port, as shown in Figure 3. Only at the observation pile outside the harbor at the estuary, were waves measured. In the Typhoon Fung-Wong event, the Shihmen Reservoir was operated for flood drainage and sediment discharge from 18:00 on 27 July 2008 to $23: 00$ on 29 July 2008 , which resulted in a rapid increase in the water flow and sediment transport in the river channel.

The overall $\mathrm{r}$ values shown in Table 2 indicate a very strong correlation in tidal levels and wave parameters (wave heights and periods) between the observations and simulations at the four measurement stations. The simulation results in Figure 5a show that the simulated water levels at the estuary tide gauge were quite close to the measured values ( $R M S E=0.10 \mathrm{~m} ; N B=0.04)$. Figure $5 \mathrm{~b}$ presents the simulated and measured water levels at the same location from September 13 to October 1 -covering the period of Typhoon Sinlaku and the period of Typhoon Jangmi (RMSE $=0.16 \mathrm{~m}$; $N B=0.13)$. Although the RMSE values were small relative to the tidal range in the area $(2.0-3.0 \mathrm{~m})$, the differences in the water levels were due to the effect of river inflows. 

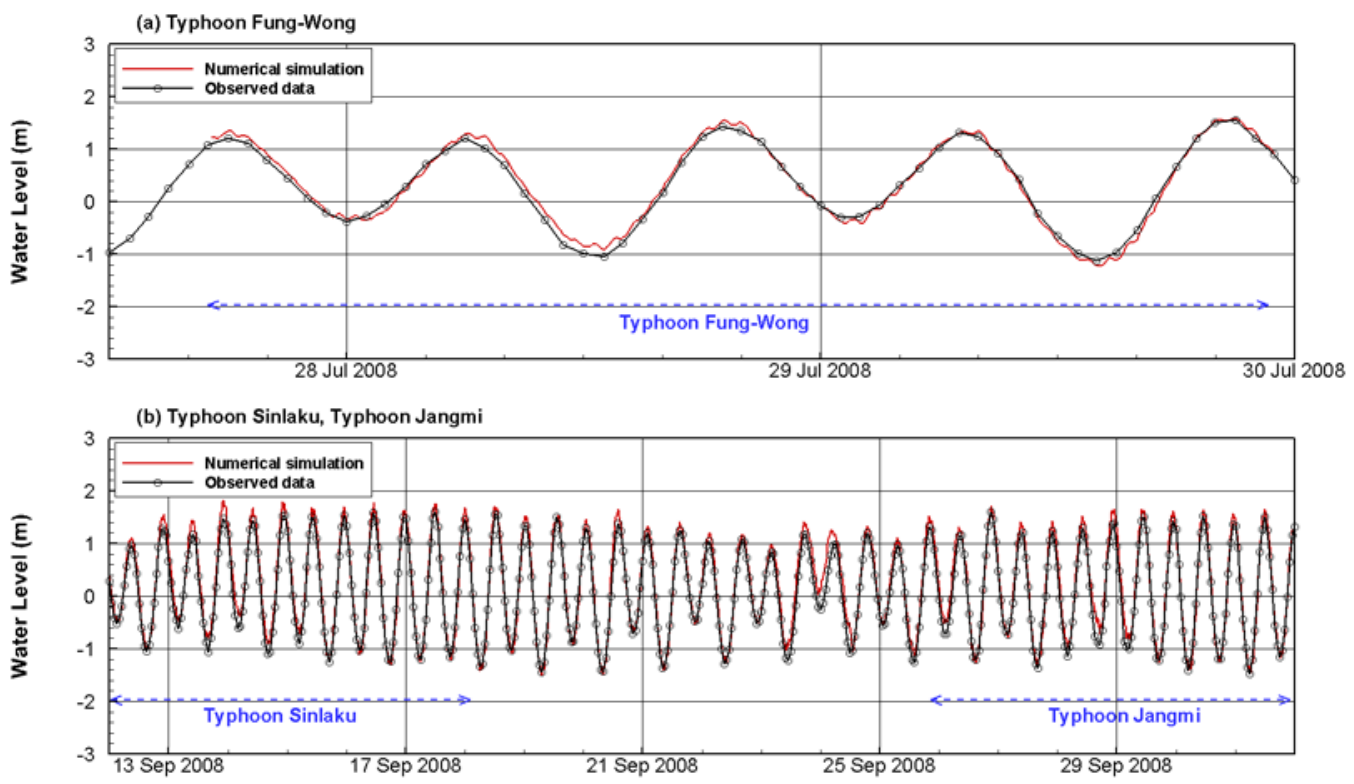

Figure 5. Comparison of simulated and observed water levels at the Estuary Tide Gauge during (a) Typhoon Fung-Wong as well as (b) Typhoon Sinlaku and Typhoon Jangmi.

The simulated water levels at the other two gauges were also close to the measured data. The maximum RMSE was $0.35 \mathrm{~m}$ at the third dock gauge inside the harbor, calculated during the period of Typhoons Sinlaku and Jangmi. The values of NB varied from -0.34 at the third dock gauge inside the harbor to +0.46 at the observation pile outside the harbor. It means that the model underestimated the water levels inside the harbor but overestimated outside. The reason for the errors could be because two gauges are too close to breakwaters of the harbor. So the measurements of the water levels may contain the effect of reflections of the structures.

In the simulation range, only one buoy was installed near the Taipei Port at a site with water bottom elevation of approximately $-10 \mathrm{~m}$ (Figure 3) for wave parameter measurement. Figure 6 presents the simulated and actual results of wave height and wave period during the periods of Typhoon Sinlaku, and Typhoon Jangmi. The results show that the wave height reached $4 \mathrm{~m}$ during the period of Typhoon Jangmi but varied between 0.4 and $0.6 \mathrm{~m}$ in the non-typhoon period. However, during the transition period from Typhoon Sinlaku to Typhoon Jangmi (Figure 6), the RMSE between the simulated and observed values of the significant wave height was only $0.42 \mathrm{~m}$, the $r$ value was 0.93 , and the $S I$ value was 0.33 , with the simulated values tending to be slightly overestimated (NB $=0.13$ ); the RMSE, $r, S I$, and NB between the simulated and observed values of the significant wave period were $0.58 \mathrm{~m}, 0.92,0.12$, and -0.01 , respectively, with the simulated values slightly lower than the observed ones. As expressed by the above quantitative indicators, CCHE2D-Coast could effectively reproduce the changes in water level, wave height, and wave period during typhoon-induced flooding periods and non-typhoon periods.

The topo-bathymetric data used in the analysis were measured by using the single-beam echosounders in 1 May 2008 and 31 October 2008. It may accurately reflect the morphological changes caused by Typhoon Fung-Wong, Typhoon Sinlaku, and Typhoon Jangmi. The total discharge of the Shihman Reservoir in three typhoon-induced flood events, respectively, were 142.83, 622.24, and 237.36 million $\mathrm{m}^{3}$ with the total sediment discharge of 3.45 million tons. Figure 7 a shows that the changes in the nearshore seabed did not comply with the sediment transport mechanism due to the anthropogenic disturbance. However, the morphological changes in the river estuary were from reasonable patterns of deposition and erosion. As indicated in Figure 4, the sediment was transported in a large quantity to the estuary and channel bed, where it was deposited due to the large river flow 
during the typhoon periods. The farthest deposition site had the water bottom elevation of $-10 \mathrm{~m}$; meanwhile, the significant morphological variation occurred within water bottom elevation of $-5 \mathrm{~m}$.
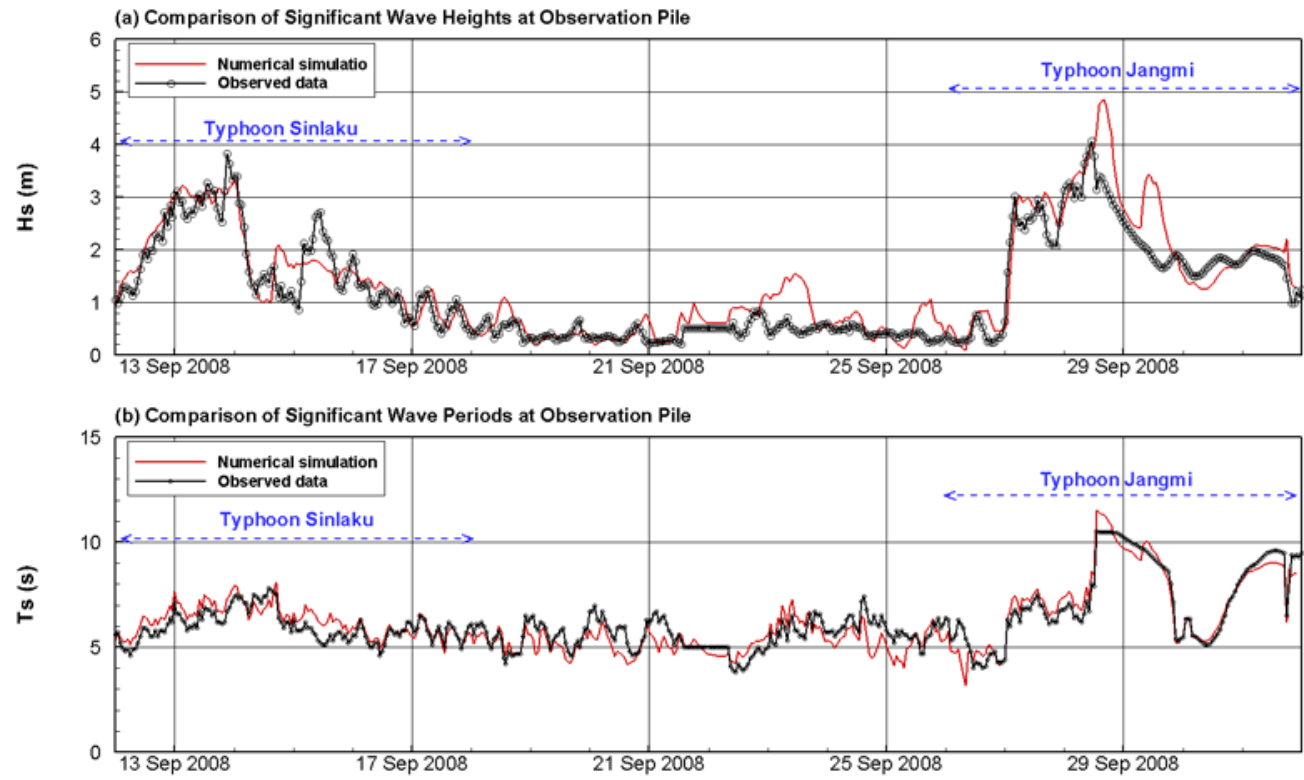

Figure 6. Comparison of simulated and observed results of (a) significant wave heights and (b) significant wave periods at the Observation Pile.

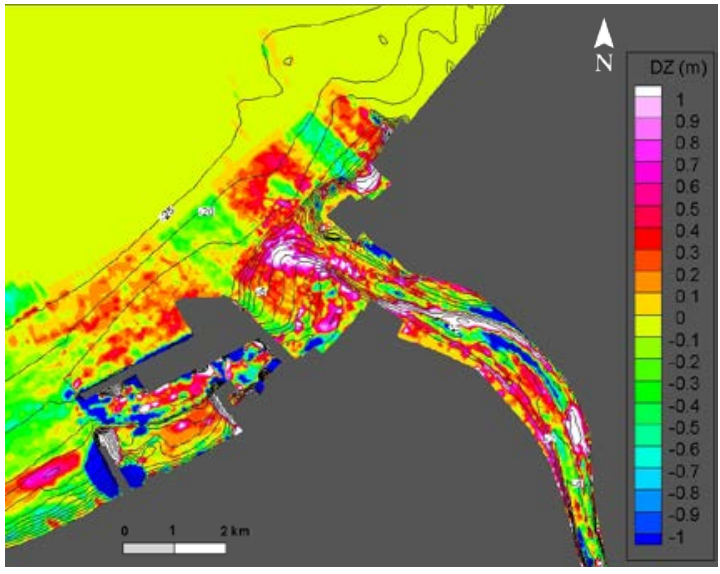

(a) Measured bed changes in the time period from 1 May 2008 to 31 October 2008

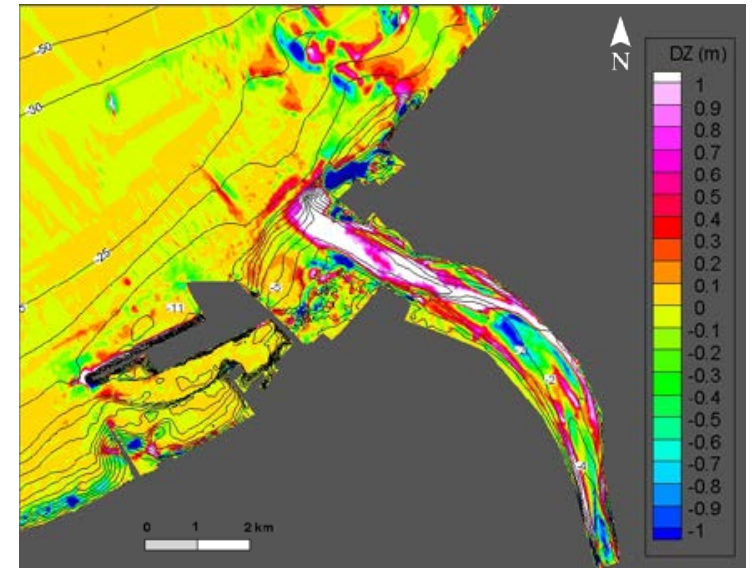

(b) Simulated bed changes through the same period

Figure 7. Comparison of measured and simulated topography of the Tamsui River estuary. (DZ = bed change, contour line is bed elevation. The unit is meter for both).

Figure $7 \mathrm{~b}$ indicates the bed changes simulated by the CCHE2D-Coast model through the same period from May to October of 2008. Comparing it with the observations in Figure 7a, the simulated bed changes have a good agreement with the observed one. The morphological changes in the tidal river reach from the river upstream of the Guandu Bridge to the river mouth have consistent variations with the field measurement. The similar depositions which occurred in the river bend were close to the concave bank and a large area of the river mouth. Although the model captures the features of the scouring and erosion close to the center of the bend, the simulated deposition at the river mouth was overestimated; the field observation showed more settling of river sediments at the south side. The simulated results also showed the less sedimentation inside the Taipei harbor. The dredging may 
be conducted near the breakwater in this period; however, the proposed model did not incorporate the effect of the anthropogenic activities. Moreover, the obvious difference in the bed change at the north shore of the river mouth could be found. The simulated erosion was driven by the simulated tidal currents and nearshore currents due to waves, while the sea bed was assumed as erodible due to lacking data. Overall, the numerical model produced reasonable results on the morphological changes in a wide range of the Tamsui River estuary. The current developed numerical models for simulating the sediment transport and morphodynamic processes are still challenging, a few factors, e.g., using spatially-varying bed materials, inclusion of dredging, sand mining activities, and fractional sediment transport load, would be further considered in the future work.

\section{Simulation Results and Discussion on Scenario of Sediment Flushing}

\subsection{Effect of Sediment Concentration on the Topography}

According to the 2012 Report "Hydraulic model studies for sediment sluicing and flood diversion engineering of Shihman Reservoir" released by the Water Resources Planning Institute, the sediment delivery ratio (outflow sediment volume/inflow sediment volume of the Shihmen Reservoir) of the reservoir after the construction of the Amuping desilting tunnel could be as high as 55.2\% [48]. In addition, the statistics of the sediment discharge amount from the afterbay of the Shihmen Reservoir from 2006 to 2017 revealed that in 2013, a total of 2.987 million tons of sediment was discharged from the reservoir during the Typhoon Soulik period, which was the highest discharge amount of sediment in recent years [49]. Therefore, this study adopted the case of the Typhoon Soulik as the base scenario with the sediment delivery ratio of $35 \%$ according to field observation.

Typhoon Soulik impacted the study area from 01:00 on 12 July 2013, to 23:00 on 19 July 2013. Therefore, the scenario from 00:00 on 1 July 2013, to 00:00 on 12 July 2013, was considered here to serve as a starting scenario, in which the time step for flow field calculation was set to $30 \mathrm{~s}$, and the time step for wave field calculation was set to $7200 \mathrm{~s}$. The situation from 30:00 on 12 July 2013, to 23:00 on 19 July 2013, was the case scenario, in which the time steps for flow field calculation and wave field calculation were set to $30 \mathrm{~s}$ and $7200 \mathrm{~s}$, respectively, and the time step for bed calculation was set to $100 \mathrm{~s}$. The topo-bathymetric data used in the model for the case scenario was measured in May 2013. The west and east boundaries were the tidal level data measured at the Linshanbi and Zhuwei Fishing Port stations. For the south boundary, the current scenario without use of the Amuping desilting tunnel and the case scenario with the use of the Amuping desilting tunnel are shown in Figure 8.

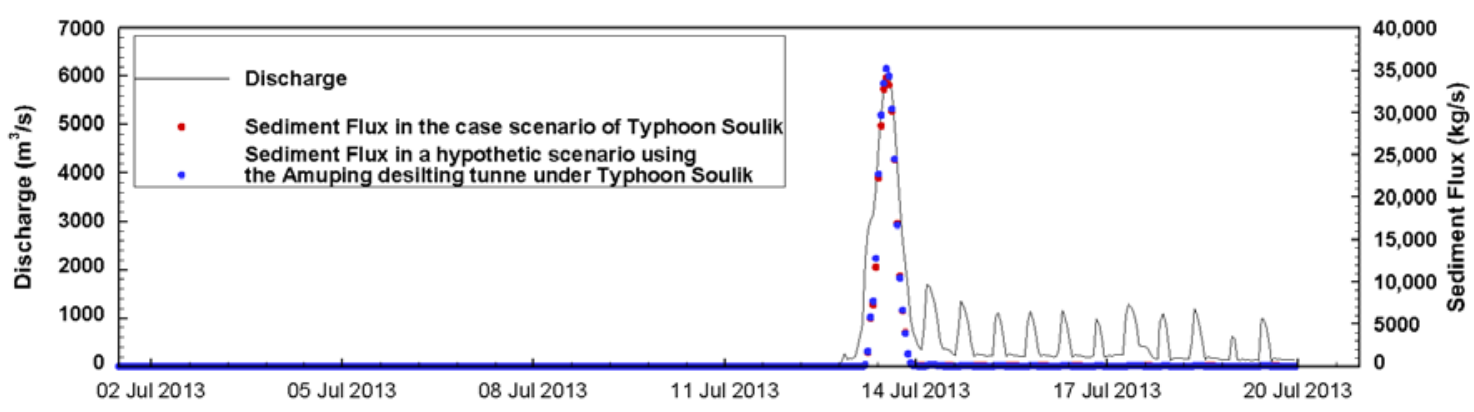

Figure 8. Time series of river flow and sediment concentration at the Guandu Bridge.

In the current scenario with Typhoon Soulik, the instant the estuary flow reached $5652 \mathrm{~m}^{3} / \mathrm{s}$ was when the high tide began to ebb (15:00 on 13 July 2013). At this time, the flood elevation reached its maximum in each area. The water levels in the river channel were approximately $1.2-1.3 \mathrm{~m}$ with a significant wave height of $0-0.4 \mathrm{~m}$; the water levels in the outside sea area were approximately 1-1.2 m with a significant wave height of approximately $0.6-1.2 \mathrm{~m}$, and the estuary was subject to a very complicated flow field (Figure 9) due to waves, tides, and the upstream flood. By 00:00 on 15 July 2013, 
Typhoon Soulik had moved away from the study area. When the flow in the estuary was $257 \mathrm{~m}^{3} / \mathrm{s}$, the water levels in the estuary and the outside sea area were between $0-0.2 \mathrm{~m}$, and the significant wave height was approximately $0-0.4 \mathrm{~m}$, as shown in Figure 10.

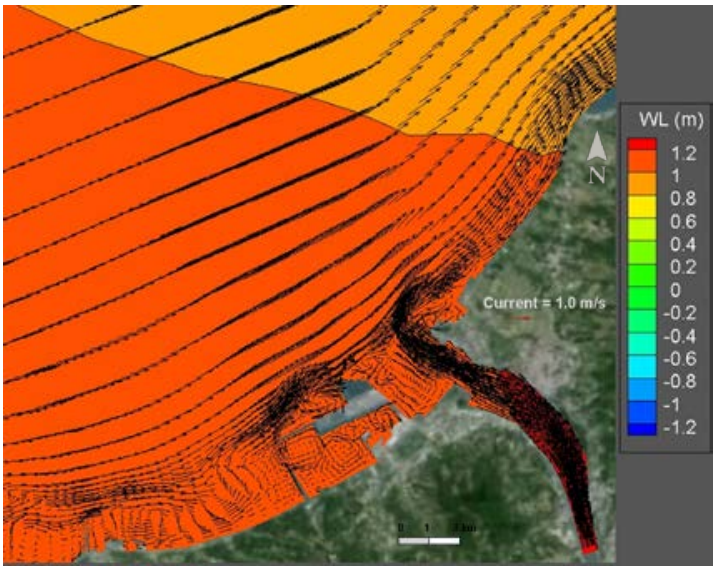

(a) Distribution of water level and flow velocity

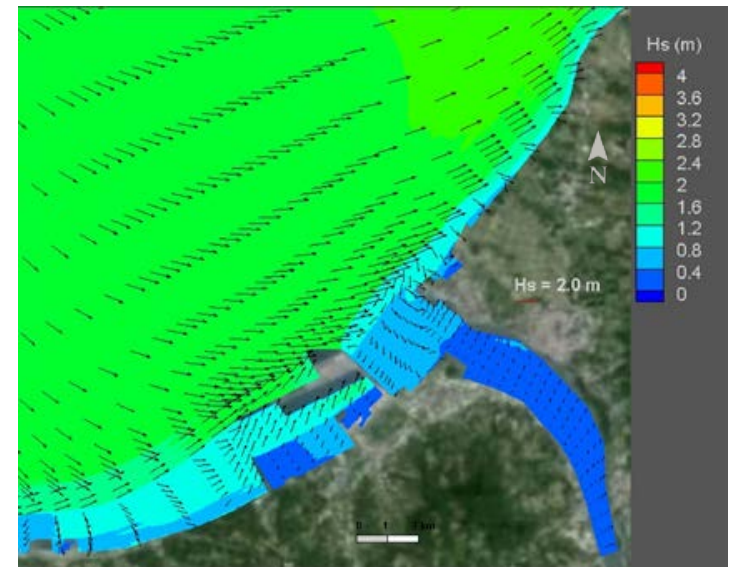

(b) Distribution of significant wave height and significant wave direction

Figure 9. The flow was $5652 \mathrm{~m}^{3} / \mathrm{s}$ at 15:00 on 13 July 2013, when the tide began to ebb.

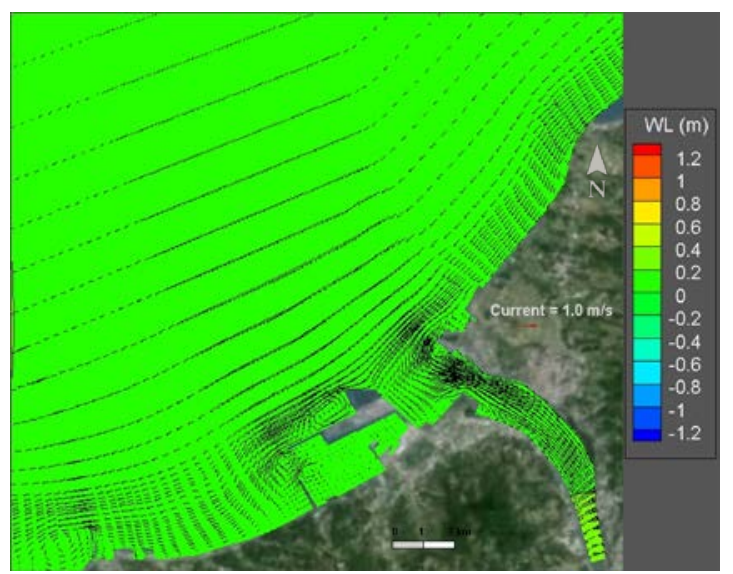

(a) Distribution of water level and flow velocity

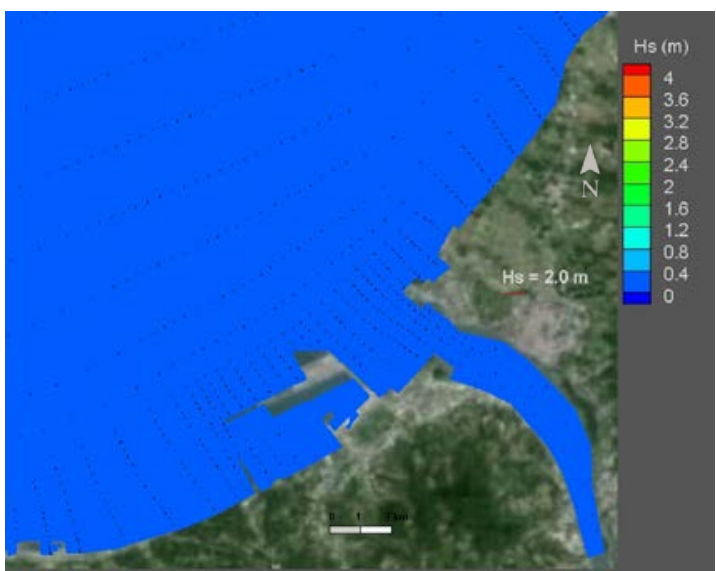

(b) Distribution of significant wave height and significant wave direction

Figure 10. The flow was $257 \mathrm{~m}^{3} / \mathrm{s}$ at 00:00 on 15 July 2013 when the tide was slack.

In response to Typhoon Soulik, the Shihmen Reservoir was operated to tentatively discharge the floodwater at 21:00 on 12 July 2013. The flow at the Guandu Bridge was approximately $273 \mathrm{~m}^{3} / \mathrm{s}$. At this time, the sediment flux of the estuary was dominated by littoral drift, which moved in the same direction as the longshore currents (Figure 11a). At 12:00 on 13 July 2013, due to the flood control and discharge operation of the Shihmen Reservoir, the flow at the Guandu Bridge reached $5786 \mathrm{~m}^{3} / \mathrm{s}$, together with the sediment flux of $33,443 \mathrm{~kg} / \mathrm{s}$ (Figure 8). At this moment, the estuarine sediment flux was dominated by the river-transported sediment (Figure 11b). The sediment was then transported by the upstream river flood to the estuary, reaching as far as the offshore around the area with the bed elevation of $-25 \mathrm{~m}$. The high sediment load was mainly concentrated on the river channel close to the right bank. At this flood peak, the computed unit-width sediment transport flux can reach up to $2.1 \times 10^{-3} \mathrm{~m}^{3} / \mathrm{s} / \mathrm{m}$, or $5.57 \mathrm{~kg} / \mathrm{s} / \mathrm{m}$. 


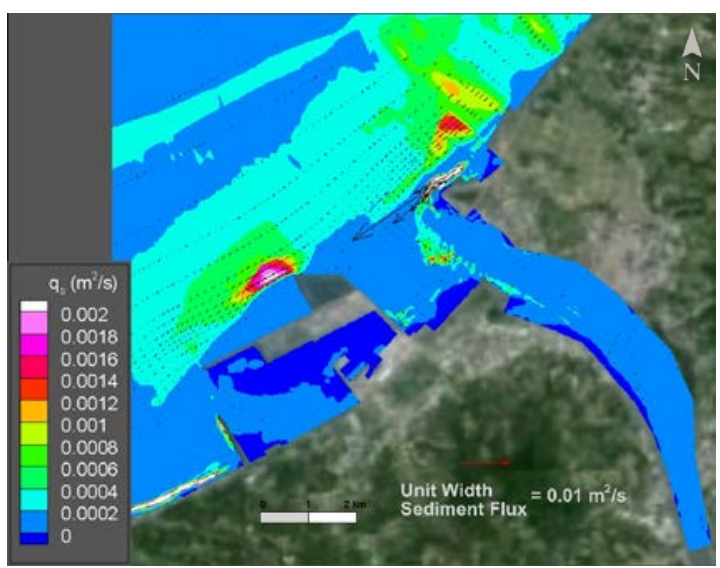

(a) 12 July 2013 21:00

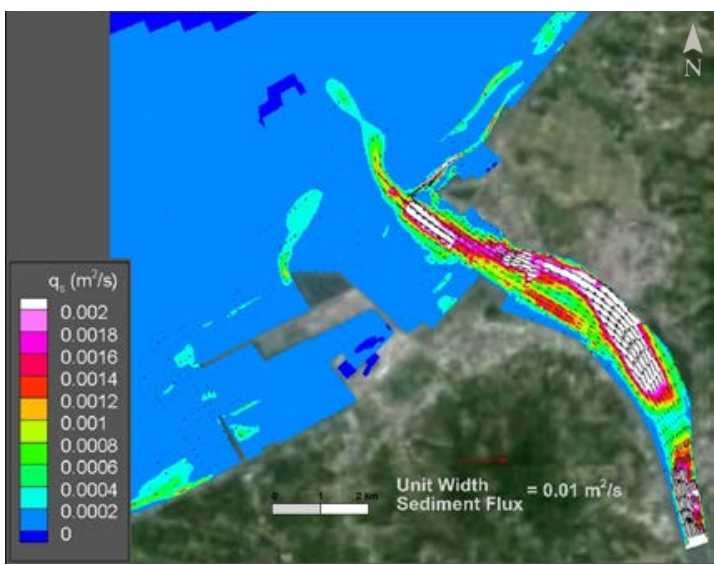

(b) 13 July 2013 12:00

Figure 11. Comparison of sediment flux $\left(\mathrm{q}_{\mathrm{s}}\right)$ at different times.

As shown in Figure 12, the bed changes were between -0.36 and $0.48 \mathrm{~m}$, and the maximum scouring depth of $-0.8 \mathrm{~m}$ was present at a site $6500 \mathrm{~m}$ far away from the Guandu Bridge. Aggradation occurred at a distance of $6800 \mathrm{~m}$ to the Guandu Bridge, with the aggradation height reaching $1.4 \mathrm{~m}$. Due to the flood drainage of the Shihmen Reservoir and the flow path characteristics, the channel of the river section $2500-4000 \mathrm{~m}$ away from the Guandu Bridge was scoured by $0.25 \mathrm{~m}$ on average, while the right bank (the Tamsui mangrove reserve) was subject to aggradation. The right bank of the estuary (5600-5800 $\mathrm{m}$ away from the Guandu Bridge) was also subjected to scouring, with an average scouring depth of $0.12 \mathrm{~m}$. Scouring and aggradation alternated in the region from the left bank of the estuary to the north breakwater of the Taipei Port, with parts of the sediment transported by the backflow to the sand spit of the Wazihwei area.

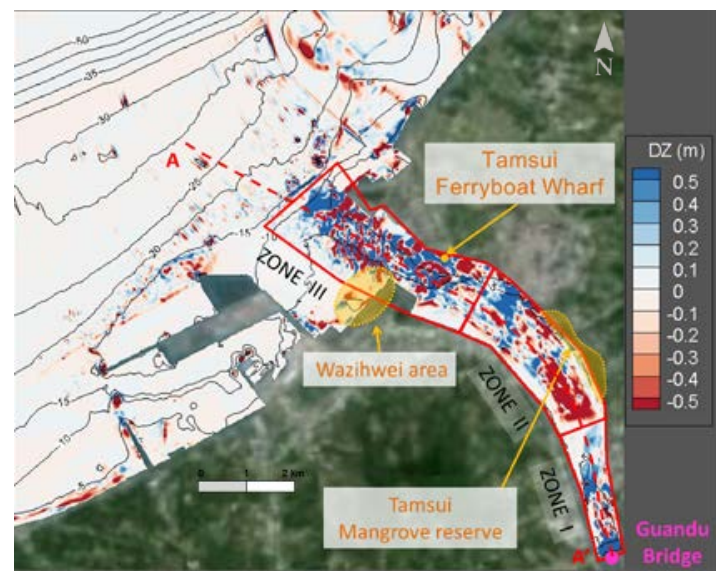

(a) Bed scouring and aggradation in the estuary

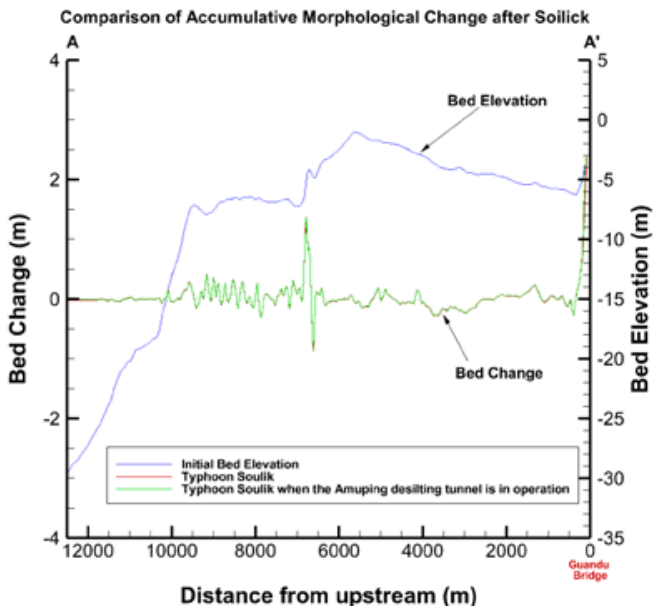

(b) Bed scouring and aggradation in the range A-A'

Figure 12. Simulated bed changes caused by Typhoon Soulik in the current situation. (DZ = bed change).

However, after the construction of the Amuping desilting tunnel, the sediment delivery ratio will be increased by $20.2 \%$ compared to the current situation. The sediment amount transported downstream will not be significantly increased if the flow is maintained unchanged. The river channel was divided into three zones for comparison. The results showed that the amount of sediment deposition would, respectively, increase around $2627 \mathrm{~m}^{3}$ and $170 \mathrm{~m}^{3}$ in ZONE I and ZONE II, whereas that would decrease $240 \mathrm{~m}^{3}$ in ZONE III, compared to the current situation as indicated in Figure 13. 


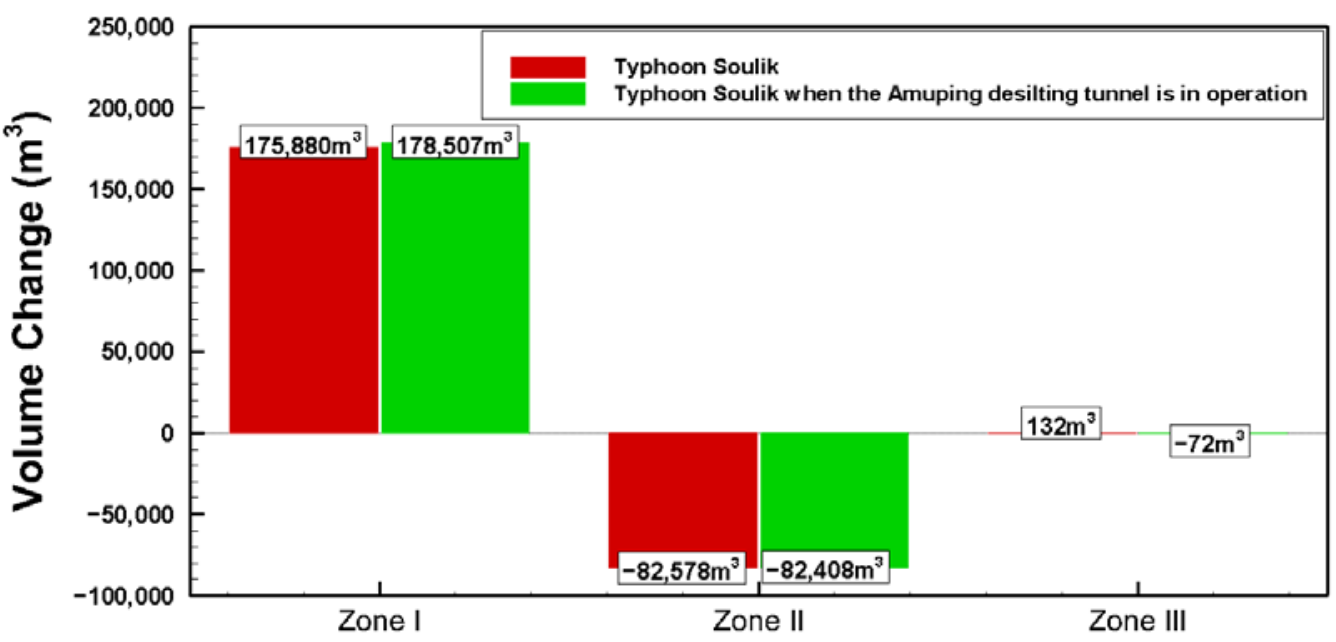

Figure 13. Simulated bed changes caused by Typhoon Soulik when the Amuping desilting tunnel is in operation.

The change in the sediment volume is minor with the operation of the Amuping desilting tunnel. However, the operation of the tunnel leads to the Reservoir Hydraulic Slag Removal volume from $1.13 \times 10^{6} \mathrm{~m}^{3}$ to $1.78 \times 10^{6} \mathrm{~m}^{3}$. It implies that the consideration of the Amuping desilting tunnel is helpful for alleviating the Shihmen Reservoir siltation with a minimal disturbance of the estuarine environment.

In summary, aggradation during the Typhoon-induced flood period occurred mainly at sites 4000-5300 m away from the Guandu Bridge (Figure 12b) and in the outside sea area of the second fishing port of Tamsui; scouring occurred mainly at sites 2500-4000 $\mathrm{m}$ and 5600-5800 $\mathrm{m}$ away from the Guandu Bridge, and in particular the Tamsui Ferryboat Wharf was in the latter range.

\subsection{Morphological Changes during the Flood and Monsoon Periods}

Changes in estuarine scouring and aggradation are closely related to the sediment transport behavior of the adjacent sea area. The currents generated by waves and tides provide a driving force for coastal sediment transport. The littoral drift at the mouth of the Tamsui River is affected by the southwest monsoon in summer, and the longshore currents move northward with the littoral drift; in winter, the region is under the influence of the northeast monsoon, and the longshore currents move southward with the littoral drift. When typhoon rainstorms arrive, the upstream Shihmen Reservoir has to perform flood discharge operations for flood control and aggradation prevention. Therefore, there is a large amount of rainfall and reservoir-discharged floodwater in the upper reaches, and the energy generated by the upstream flood discharge is much larger than the ocean current energy, making the upstream flow the main factor responsible for morphological changes and water level rise in the Tamsui River estuary.

To understand the difference between the monsoon period and the Typhoon-induced flood period in causing morphological changes in the Tamsui River estuary, this study simulated the bed changes with the scenarios of the monsoon period from 1 December 2009, to 28 February 2010, and Typhoon Aere in 2004. The former scenario caused the largest water level in the Tamsui River Estuary tide gauge while the latter one led to the largest recorded flood event in the study region. Thus, such consideration would be helpful to explore the difference between the monsoon period and the Typhoon-induced flood period in causing morphological changes in the Tamsui River estuary. This typhoon caused the largest recorded flood event in the study region, with the maximum discharge rate of Shihmen Reservoir reaching $8366 \mathrm{~m}^{3} / \mathrm{s}$, between $\mathrm{Q}_{50}$ and $\mathrm{Q}_{100}$. Notice that $\mathrm{Q}_{50}$ and $\mathrm{Q}_{100}$ denote the 50-year and 100-year return periods of discharge, respectively. Additionally, the values of $Q_{50}$ and $Q_{100}$ at the cross-section No. T075 were respectively $7800 \mathrm{~m}^{3} / \mathrm{s}$ and $8400 \mathrm{~m}^{3} / \mathrm{s}$. The cross-section No. T075 is 
located about $10.6 \mathrm{~km}$ downstream of the Shihmen Reservoir. As shown in Figure 14a, during the monsoon period, the upstream sediment source was reduced in strength owing to the small river flow, and thus, the morphological changes in the estuary were mainly determined by littoral drift. Under the influence of the northeast monsoon, littoral drift would form a northeast-southwest-oriented rod-shaped aggradation pattern to the north of the second fishing port, and the sediment will be gradually transported into the second fishing port owing to the impact of the tide. When the currents flowed to the north breakwater of the Taipei Port, backflow was generated due to the breakwater obstruction, transporting the sediment of the Wazihwei sand spit to the left bank of the estuary.

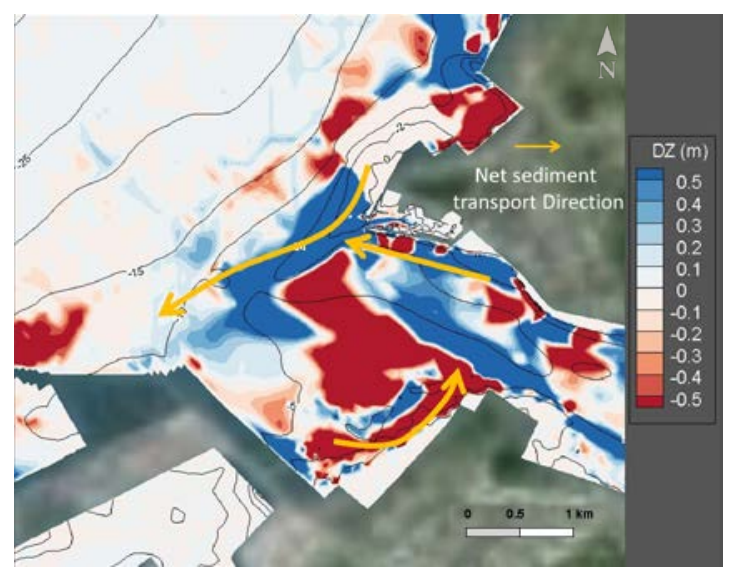

(a) End of the monsoon period

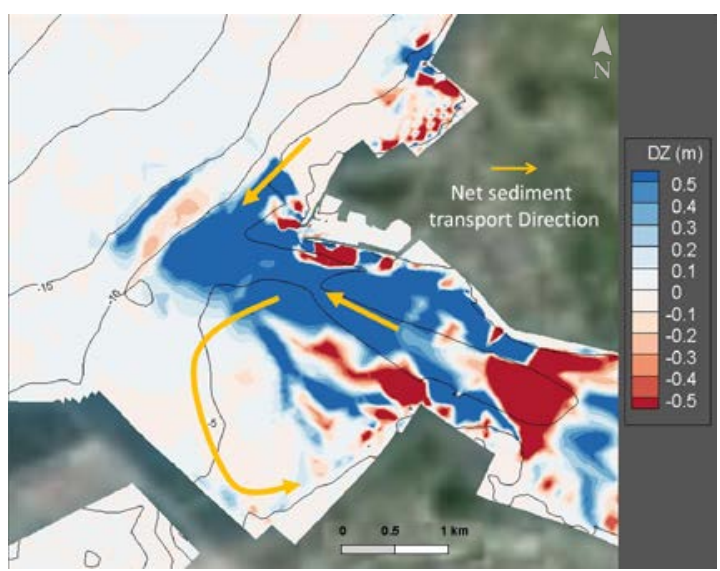

(b) End of the typhoon period

Figure 14. Diagram of morphological change in the Tamsui River estuary. (DZ = bed change).

During the Typhoon-induced flood period, owing to the rainfall and the flood discharge of the Shihmen Reservoir, the sediment was transported by the flood. Concave banks were dominant in the river channel 2500-4000 $\mathrm{m}$ away downstream from the Guandu Bridge and the flow was fast in this section, which was subjected to scouring; the river channel 6000-7000 $\mathrm{m}$ away from the bridge was also subjected to scouring, mainly owing to the bed type. However, the riverine section within $2500 \mathrm{~m}$ downstream of the Guandu Bridge and the estuarine section within $2500 \mathrm{~m}$ seaward from the river mouth (7500-10,000 m downstream of the Guandu Bridge) were mainly subjected to aggradation. The sediment in the outside sea area was affected by the sea currents, and parts of the sediment spread to the Wazihwei sand spit owing to longshore currents (Figure 14b). A comparison of the simulation results under the two scenarios of Typhoon Soulik and Typhoon Aere revealed that the growth of the Wazihwei sand spit was affected by the amount of flood discharge during the typhoon-induced flood period, while the aggradation in the second fishing port was mainly attributed to the littoral drift during the monsoon period.

\section{Conclusions}

To evaluate the trend of riverbed change by numerical modeling, the relevant model parameters were first validated using the 2008 events of Typhoons Fung-Wong, Sinlaku, and Jangmi, allowing the CCHE2D-Coast model to effectively reproduce the complex flow fields and sediment transport processes at the Tamsui River estuary, such as flooding, erosion, and aggradation along the coast, along with scouring of the estuarine sandbar. Next, this model was used to explore the effects that the operation of the Amuping desilting tunnel of Shihmen Reservoir would have on the downstream river channel, and to compare the sediment transport characteristics in the Tamsui River estuary during typhoon-induced flood and a period with the monsoon.

The results showed that for sediment transport during the typhoon-induced flood period, the upstream flood transported a large amount of sediment to be deposited in the estuary, and parts of 
sediment were transported by currents to the Wazihwei sand spit where they were deposited. Under the condition that the flow is kept unchanged and the sediment concentration is increased (after the construction of the Amuping desilting tunnel), the sediment transport capacity of the river water will be reduced, which in turn would increase the degree of aggradation in the river channel while slowing down of aggradation in the estuary. During the monsoon period, sedimentation was mainly determined by ocean currents, and the transport was also subject to coastal topo-bathymetry, coastal structures, and tidal currents. The sediment is deposited in the outside area of the second fishing port of Tamsui, the north breakwater of the Taipei Port, and in the estuarine areas. The Wazihwei sand spit would be subject to aggradation due to backflow. As to whether these processes would further lead to long-term morphological changes in the Wazihwei sand spit, it is necessary to address the issue by incorporating numerical modeling with topo-bathymetric data and satellite imagery in the future. Meanwhile, the Wazihwei area is in a nature reserve, and the effectiveness of conducting sediment management to maintain the sandbar area also can be evaluated by numerical modeling.

This numerical simulation study reproduced the changes in hydrodynamics and morphodyanmics of the Tamsui River estuary and will facilitate the management of sediment transport in the Tamsui River Estuary driven by multiple coastal and estuarine processes, such as waves, tidal currents, and river flows.

Author Contributions: T.-C.H. collected the data, performed the statistical and simulating analysis, and drafted and revised the manuscript. Y.D. conceived of the study, performed model validation and simulations of design scenarios, participated in its design and coordination and drafted and revised the manuscript. K.-C.Y. participated in the design of the study and coordination, provided methods. R.-K.J. participated in the design of the study and performed river simulations using CCHE1D. All authors have read and agreed to the published version of the manuscript.

Funding: This research received no external funding.

Acknowledgments: Parts of the contents in this study are derived from the outcomes of a commissioned project of the Tenth River Management Office of the Water Resources Agency, Ministry of Economic Affairs. The authors would like to thank the anonymous reviewers and editor for their constructive comments which profoundly improve the manuscript.

Conflicts of Interest: The authors declare no conflict of interest

\section{References}

1. Shimizu, T.; Kumagai, T.; Watanabe, A. Improved 3-D Beach Evolution Model Coupled with the Shoreline Model (3D-SHORE). Coast. Eng. 1997, 3, 2843-2856.

2. Reniers, A.J.; Roelvink, D.; Thornton, E.B. Morphodynamic modeling of an embayed beach under wave group forcing. J. Geophys. Res. Space Phys. 2004, 109. [CrossRef]

3. Ding, Y.; Wang, S.S.Y. Development and Application of a Coastal and Estuarine Morphological Process Modeling System. J. Coast. Res. 2008, 10052, 127-140. [CrossRef]

4. Roelvink, D. Coastal morphodynamic evolution techniques. Coast. Eng. 2006, 53, 277-287. [CrossRef]

5. Ding, Y.; Kuiry, S.; Elgohry, M.; Jia, Y.; Altinakar, M.S.; Yeh, K.-C. Impact assessment of sea-level rise and hazardous storms on coasts and estuaries using integrated processes model. Ocean Eng. 2013, 71, 74-95. [CrossRef]

6. Tenth River Management Office. Impact Assessment of Sediment Transport at Tansui Estuary on surrounding coast (1/2); The Tenth River Management Office, Water Resources Agency: New Taipei City, Taiwan, 2014. (In Chinese)

7. Northern Region Water Resources Office. Available online: https://www.wranb.gov.tw/public/Attachment/ 652011311785.pdf (accessed on 15 October 2019).

8. Northern Region Water Resources Office. Feasibility Study of Amouping Desilting Tunnel Project for Shihmen Reservoir Summary Report; The Northern Region Water Resources Office, Water Resources Agency: Taoyuan, Taiwan, 2015. (In Chinese)

9. Bakker, W.T.; Doorn, T.V. Near-Bottom Velocities in Waves with a Current. Coast. Eng. 1978, 1394-1413.

10. Kemp, P.H.; Simons, R. The interaction between waves and a turbulent current: Waves propagating with the current. J. Fluid Mech. 1982, 116, 227. [CrossRef] 
11. Kemp, P.H.; Simons, R. The interaction of waves and a turbulent current: Waves propagating against the current. J. Fluid Mech. 1983, 130, 73. [CrossRef]

12. Visser, P.J. Wave basin experiments on bottom friction due to current and waves. Coast. Eng. Proc. 1986, 1, 61. [CrossRef]

13. Asano, T.; Nakagawa, M.; Iwagaki, Y. Changes in current properties due to wave superimposing. Coast. Eng. Proc. 1986, 1, 70. [CrossRef]

14. Simons, R.R.; Kyriacou, A.G.; Soulsby, R.L.; Davies, A.G. Predicting the nearbed turbulent flow in waves and currents. In Proceedings of the IAHR Symposium on Mathematical Modelling of Sediment Transport in the Coastal Zone, Copenhagen, Denmark, 1988; pp. 33-47. Available online: https://discovery.ucl.ac.uk/id/ eprint/1520924/ (accessed on 4 April 2020).

15. Sleath, J.F.A. Velocities and Bed Friction in Combined Flows. Coast. Eng. 1991, 450-463.

16. Arnskov, M.; Fredsøe, J.; Sumer, B. Bed shear stress measurements over a smooth bed in three-dimensional wave-current motion. Coast. Eng. 1993, 20, 277-316. [CrossRef]

17. Lundgren, H. Turbulent Currents in the Presence of Waves. Coast. Eng. 1972, 623-634.

18. Smith, J.D. Modeling of Sediment Transport on Continental Shelves; The Sea 6; Wiley Interscience: New York, NY, USA, 1977; pp. 539-577.

19. Grant, W.D.; Madsen, O.S. Combined wave and current interaction with a rough bottom. J. Geophys. Res. Space Phys. 1979, 84, 1797-1808. [CrossRef]

20. Fredsøe, J. Turbulent Boundary Layer in Wave?current Motion. J. Hydraul. Eng. 1984, 110, 1103-1120. [CrossRef]

21. Christoffersen, J.B.; Jonsson, I.G. Bed friction and dissipation in a combined current and wave motion. Ocean Eng. 1985, 12, 387-423. [CrossRef]

22. Coffey, F.C.; Nielsen, P. The Influence of Waves on Current Profiles. Coast. Eng. 1987, 82-96. [CrossRef]

23. Myrhaug, D.; Slaattelid, O.H. Combined wave and current boundary layer model for fixed rough seabeds. Ocean Eng. 1989, 16, 119-142. [CrossRef]

24. Chen, Q.; Madsen, P.A.; Schäffer, H.A.; Basco, D.R. Wave-current interaction based on an enhanced Boussinesq approach. Coast. Eng. 1998, 33, 11-39. [CrossRef]

25. Nwogu, O.G.; Demirbilek, Z. BOUSS-2D: A Boussinesq Wave Model for Coastal Regions and Harbors. In BOUSS-2D: A Boussinesq Wave Model for Coastal Regions and Harbors; Defense Technical Information Center (DTIC), 2001; Available online: https://erdc-library.erdc.dren.mil/jspui/handle/11681/7555 (accessed on 4 April 2020).

26. Booij, N.; Ris, R.C.; Holthuijsen, L. A third-generation wave model for coastal regions: 1. Model description and validation. J. Geophys. Res. Space Phys. 1999, 104, 7649-7666. [CrossRef]

27. Yan, D.; Sam, S.Y.W. Modeling of wave-current interaction using a multidirectional wave-action balance equation. Coast. Eng. Proc. 2011, 1. [CrossRef]

28. Lodahl, C.R.; Sumer, B.; Fredsøe, J. Turbulent combined oscillatory flow and current in a pipe. J. Fluid Mech. 1998, 373, 313-348. [CrossRef]

29. Simons, R.; Grass, T.J.; Mansour-Tehrani, M. Bottom Shear Stresses in the Boundary Layers under Waves and Currents Crossing at Right Angles. Coast. Eng. 1993, 604-617. [CrossRef]

30. Simons, R.; Grass, T.J.; Saleh, W.M.; Tehrani, M.M. Bottom Shear Stresses under Random Waves with a Current Superimposed. Coast. Eng. 1995, 565-578. [CrossRef]

31. Van Rijn, L.C. Sedimentation of Dredged Channels by Currents and Waves. J. Waterw. Port Coast. Ocean Eng. 1986, 112, 541-559. [CrossRef]

32. Roos, P.C.; Hulscher, S.J.M.H.; De Vriend, H.J. Modelling the morphodynamic impact of offshore sandpit geometries. Coast. Eng. 2008, 55, 704-715. [CrossRef]

33. Benedet, L.; List, J.H. Evaluation of the physical process controlling beach changes adjacent to nearshore dredge pits. Coast. Eng. 2008, 55, 1224-1236. [CrossRef]

34. Faraci, C.; Foti, E.; Marini, A.; Scandura, P. Waves Plus Currents Crossing at a Right Angle: Sandpit Case. J. Waterw. Port Coast. Ocean Eng. 2012, 138, 339-361. [CrossRef]

35. Blumberg, A.F.; Mellor, G.L. A description of a three-dimensional coastal ocean circulation model. In Oceanography of the Southeastern U.S. Continental Shelf; American Geophysical Union (AGU), 1987; Volume 4, pp. 1-16. Available online: https://doi.org/10.1029/CO004p0001 (accessed on 4 April 2020). 
36. Jelesnianski, C.; Chen, J.; Shaffer, W. SLOSH: Sea, Lake, and Overland Surges from Hurricanes; NOAA Tech Report; 1992; Available online: https://www.hsdl.org/?abstract\&did=779560 (accessed on 4 April 2020).

37. SLOSH. 2008. Available online: http://www.nhc.noaa.gov/HAW2/english/surge/slosh.shtml (accessed on 16 January 2008).

38. Svendsen, I.A.; Haas, K.; Zhao, Q. Quasi-3D Nearshore Circulation Model SHORECIRC—Version 2.0; Technical Report; Center for Applied Coastal Research, University of Delaware: Newark, NJ, USA, 2003.

39. A Svendsen, I.; Qin, W.; A Ebersole, B. Modelling waves and currents at the LSTF and other laboratory facilities. Coast. Eng. 2003, 50, 19-45. [CrossRef]

40. Zyserman, J.A.; Johnson, H.K. Modelling morphological processes in the vicinity of shore-parallel breakwaters. Coast. Eng. 2002, 45, 261-284. [CrossRef]

41. Tuan, T.Q.; Stive, M.J.F.; Verhagen, H.J.; Visser, P.J. Process-based modeling of the overflow-induced growth of erosional channels. Coast. Eng. 2008, 55, 468-483. [CrossRef]

42. Kuiry, S.; Ding, Y.; Wang, S.S.Y. Modelling coastal barrier breaching flows with well-balanced shock-capturing technique. Comput. Fluids 2010, 39, 2051-2068. [CrossRef]

43. Faraci, C.; Scandura, P.; Foti, E. Bottom Profile Evolution of a Perched Nourished Beach. J. Waterw. Port Coast. Ocean Eng. 2014, 140, 04014021. [CrossRef]

44. Ding, Y.; Zhang, Y.-X.; Jia, Y.-F. CCHE2D-Coast: Model Description and Graphical User Interface; NCCHE Technical Report; The University of Mississippi: Oxford, MS, USA, 2016; 88p

45. Ding, Y.; Yeh, K.-C.; Wei, S.-T. Integrated coastal process modeling and impact assessment of floating and sedimentation in coasts and estuaries. Coast. Eng. Proc. 2017, 1, 18. [CrossRef]

46. Zhang, Y.X. CCHE-GUI_Graphical Users Interface for NCCHE Models User's Manual_Version 4.x; Technical Report No. NCCHE-TR-2013-01; 2013; Available online: https://www.researchgate.net/publication/ 283153483_CCHE2D-GUI-Graphical_User_Interface_for_the_CCHE2D_Model_User $\backslash T 1 \backslash$ textquoterights_ Manual-Version_22 (accessed on 4 April 2020).

47. Harbor and Marine Technology Center. Available online: https://www.ihmt.gov.tw/ (accessed on 15 October 2019).

48. Water Resources Planning Institute. Hydraulic Model Studies for Sediment Sluicing and Flood Diversion Engineering of Shihman Reservoir; Water Resources Planning Institute, Water Resources Agency: Taichung, Taiwan, 2012. (In Chinese)

49. Water Resources Planning Institute. Sediment Transport Monitoring Facility Maintenance and Flood Event Observations in Shihmen Reservoir; Water Resources Planning Institute, Water Resources Agency: Taichung, Taiwan, 2016. (In Chinese) 